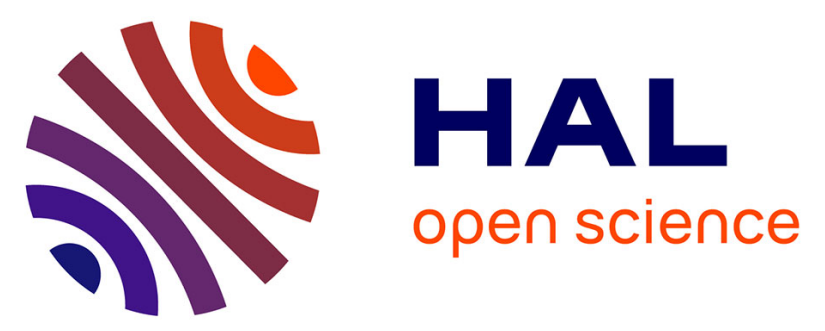

\title{
Metyrapone blunts stress-induced hyperthermia and increased locomotor activity independently of glucocorticoids and neurosteroids.
}

Jean-Baptiste Drouet, Virginie Michel, André Peinnequin, Antonia Alonso, Nadine Fidier, Renaud Maury, Alain Buguet, Raymond Cespuglio, Frédéric Canini

\section{To cite this version:}

Jean-Baptiste Drouet, Virginie Michel, André Peinnequin, Antonia Alonso, Nadine Fidier, et al. Metyrapone blunts stress-induced hyperthermia and increased locomotor activity independently of glucocorticoids and neurosteroids.. Psychoneuroendocrinology, 2010, 35 (9), pp.1299-310. 10.1016/j.psyneuen.2010.03.001 . inserm-00593914

\section{HAL Id: inserm-00593914 https://www.hal.inserm.fr/inserm-00593914}

Submitted on 27 Sep 2011

HAL is a multi-disciplinary open access archive for the deposit and dissemination of scientific research documents, whether they are published or not. The documents may come from teaching and research institutions in France or abroad, or from public or private research centers.
L'archive ouverte pluridisciplinaire HAL, est destinée au dépôt et à la diffusion de documents scientifiques de niveau recherche, publiés ou non, émanant des établissements d'enseignement et de recherche français ou étrangers, des laboratoires publics ou privés. 


\title{
Metyrapone blunts stress-induced hyperthermia and increased locomotor activity independently of glucocorticoids and neurosteroids
}

\author{
Jean-Baptiste Drouet $^{a, *}$, Virginie Michel $^{a}$, André Peinnequin $^{b}$, \\ Antonia Alonso ${ }^{c}$, Nadine Fidier ${ }^{a}$, Renaud Maury ${ }^{a}$, Alain Buguet ${ }^{d}$, \\ Raymond Cespuglio $^{d}$, Frédéric Canini $^{a}$
}

\footnotetext{
a Département des environnements opérationnels, Institut de Recherche Biomédicale des Armées (IRBA-CRSSA), 24 Avenue des Maquis du Grésivaudan, F-38702 La Tronche Cedex, France

${ }^{\mathrm{b}}$ Département de Radiobiologie et de Radiopathologie, Institut de Recherche Biomédicale des Armées (IRBA-CRSSA), La Tronche, France

'Laboratoire d'Analyse Biologique, Institut de Recherche Biomédicale des Armées (IRBA-CRSSA), La Tronche, France

'Université Claude-Bernard Lyon 1, Faculté de Médecine, EA 4170 Radicaux libres, substrats énergétiques et physiopathologie cérébrale, 8 Avenue Rockefeller, F-69373 Lyon, France
}

Received 29 September 2009; received in revised form 1 March 2010; accepted 1 March 2010

\author{
KEYWORDS \\ Locomotor activity; \\ Stress-induced \\ hyperthermia; \\ Corticosterone; \\ Neuroactive steroids; \\ EEG; \\ Arousal
}

\begin{abstract}
Summary Metyrapone, a cytochrome $\mathrm{P}_{450}$ inhibitor used to inhibit corticosterone synthesis, triggers biological markers of stress and also reduces stress-induced anxiety-like behaviors. To address these controversial effects, 6 separate investigations were carried out. In a first set of investigations, abdominal temperature $\left(T_{\mathrm{abd}}\right)$, spontaneous locomotor activity $\left(\mathrm{A}_{\mathrm{S}}\right)$ and electroencephalogram (EEG) were recorded in freely moving rats treated with either saline or $150 \mathrm{mg} \mathrm{kg}^{-1}$ metyrapone. An increase in $T_{\mathrm{abd}}$ and $\mathrm{A}_{\mathrm{s}}$ occurred in saline rats, while, metyrapone rats exhibited an immediate decrease, both variables returning to basal values $5 \mathrm{~h}$ later. Concomitantly, the EEG spectral power increased in the gamma and beta 2 bands and decreased in the alpha frequency band, and the EMG spectral power increased. This finding suggests that metyrapone depressed stress-induced physiological response while arousing the animal. In a second step, restraint stress was applied $5 \mathrm{~h}$ after injection. Metyrapone significantly blunted the stress-induced $T_{\mathrm{abd}}$ and $\mathrm{A}_{\mathrm{s}}$ rise, without affecting the brain c-fos mRNA increase. Corticosterone ( 5 and $40 \mathrm{mg} \mathrm{kg}^{-1}$ ) injected concomitantly to metyrapone failed to reverse the observed metyrapone-induced effects in $T_{\mathrm{abd}}$ and $A_{s}$. Finasteride ( $50 \mathrm{mg} \mathrm{kg}^{-1}$ ), which blocks neurosteroid production, was also unable to block these effects. In conclusion, metyrapone acutely reduced stress-induced physiological response in freely behaving rats independently from glucocorticoids and neurosteroids.
\end{abstract}

(C) 2010 Elsevier Ltd. All rights reserved.

\footnotetext{
* Corresponding author. Tel.: +33 4766369 49; fax: +33 476636945.

E-mail address: jb.drouet@crssa.net (J.-B. Drouet).
} 


\section{Introduction}

Metyrapone is a cytochrome $\mathrm{P}_{450}$ inhibitor (Williamson and O'Donnell, 1969) that blocks the $11 \beta$-hydroxylation of deoxycorticosterone (DOC) into corticosterone in the adrenal cortex (Jenkins et al., 1958). It has been extensively used in rodents to study the role of glucocorticoids in stress processes (Mousa et al., 1981; Haleem et al., 1988; Calvo et al., 1998; Mikics et al., 2005). However, metyrapone administration leads to apparently contradictory findings.

Metyrapone limits stress-induced behaviors. Metyrapone reduces immobility time when administrated one (Healy et al., 1999) or $3 \mathrm{~h}$ (Baez and Volosin, 1994) prior to forced swim test. Its administration $3 \mathrm{~h}$ before inescapable footshock exposure also decreases the percentage of inactive trials during the test (Baez et al., 1996). These behavioral changes occurring during stress exposure are likely to reflect a decrease in stress-induced anxiety. The subsequent anxiety-like behaviors are also reduced $24 \mathrm{~h}$ after stressor exposure. Metyrapone administration $3 \mathrm{~h}$ prior restraint exposure increases the time spent in open arms during an elevatedplus-maze test carried out 1 day after (Calvo et al., 1998; Calvo and Volosin, 2001).

Conversely, as stated by Rotllant et al. (2002), "metyrapone can act as a stressor". Metyrapone increases c-fos mRNA expression in the hypothalamic paraventricular nucleus (PVN) (Herman et al., 1992) and Fos-like immunostaining throughout the brain (Rotllant et al., 2002). Metyrapone also activates the hypothalamo-pituitary-adrenocorticotrope (HPA) axis. The heteronuclear corticotropin-releasing factor (CRF) mRNA transcription is enhanced in the PVN (Herman et al., 1992) and vasopressin and CRF concentrations are increased in the pituitary portal blood (Conte-Devolx et al., 1992). Plasma ACTH concentration rises (Conte-Devolx et al., 1992; Herman et al., 1992; Rotllant and Armario, 2005) as well as that of 11desoxycortisol (Conte-Devolx et al., 1992) and deoxycorticosterone (DOC, Krugers et al., 2000).

In order to examine the apparent controversial effects of metyrapone administration (anxiolysis concomitant to brain activation), a set of 6 investigations was carried out in freely moving rats. The first experimental step aimed at analyzing the immediate and delayed reactions to the injection of metyrapone through measuring two physiological variables. Abdominal temperature ( $\left.T_{\text {abd }}\right)$ was taken to approach anxiolytic properties of metyrapone through the stress-induced hyperthermia paradigm (Bouwknecht et al., 2007; Vinkers et al., 2009). Spontaneous locomotor activity $\left(A_{S}\right)$ was recorded because it increases after social conflict (Sgoifo et al., 2002) and saline injection (Marinelli et al., 1997). Brain activation was assessed by recording the electroencephalogram (EEG). Arousal is reflected by fast $\beta 2(19-30 \mathrm{~Hz})$ and $\gamma$ ( $\gamma 1: 30-35 \mathrm{~Hz}$ and $\gamma 2: 35-50 \mathrm{~Hz}$ ) frequency bands (Maloney et al., 1997). Variations in locomotor activity are associated with variations in the $\theta(4-8 \mathrm{~Hz})$ band (Oddie and Bland, 1998). It increases with locomotion speed (Slawinska and Kasicki, 1998), but disappears when the animal is immobile (Whishaw and Vanderwolf, 1971). The second experimental step aimed at analyzing the effects of stress by applying a 60 -min restraint after the extinction of the immediate response to metyrapone administration. The effects of metyrapone on stress-induced physiological activation were addressed using the time course of $T_{\mathrm{abd}}$ and $A_{s}$. The cerebral effects were assessed using brain c-fos mRNA expression (Chan et al., 1993). Metabolic effects of metyrapone administration were quantified in the blood using glycaemia, which increases after metyrapone (Werner, 1988; Rotllant et al., 2002) and stress (Armario et al., 1990), triglyceride concentration, which decreases after stress (Ricart-Jané et al., 2002), and lactate concentration, a marker of anaerobic metabolism. The role of the inhibition of glucocorticoid synthesis in the effects observed after metyrapone administration was evaluated through corticosterone supplementation. The place of the increased DOC production (Krugers et al., 2000) was analyzed by blocking the 5 - $\alpha$ reductase using finasteride (Lephart et al., 1996). In fact, the transformation of DOC into tetrahydro-DOC (THDOC) by 3and 5- $\alpha$ reductases (Raven et al., 1996; Rupprecht et al., 1998) acts as a positive modulator of $\mathrm{GABA}_{\mathrm{A}}$ receptor (Reddy, 2006).

\section{Methods}

\subsection{Animals}

The investigation was conducted in 250 male OFA SpragueDawley rats (Charles River Laboratories, L'arbresle, France) weighing $175-200 \mathrm{~g}$ upon arrival at the laboratory. Animals were housed at constant temperature $\left(23 \pm 2{ }^{\circ} \mathrm{C}\right)$ and relative humidity $(50 \pm 10 \%)$, and in a $12 \mathrm{~h}-12 \mathrm{~h}$ light-dark cycle (light on at $0800 \mathrm{~h}$ ). The rats were accustomed to laboratory conditions during 10 days before surgery and were allowed 10 days to recover from the surgical operation. They were weighed 5 days a week to reduce handling stress (Briese and de Quijada, 1970). Experimental procedures were approved by the institutional ethics committee for animal care and performed in accordance with the principles of animal care (NIH publication no. 86-23, revised 1985) and the European Community Council Directive (86/609 EEC).

\subsection{Drugs}

Metyrapone was purchased from Interchim (Montluçon, France) for investigations no. 1, 3 and 6 (Fig. 1) and from Sigma-Aldrich (St-Quentin Fallavier, France) for investigations no. 2, 4 and 5 (Fig. 1). The substance was dissolved in $1 \mathrm{ml}$ sterile saline (SAL) and injected IP. The chosen dosage was $150 \mathrm{mg} \mathrm{kg}^{-1}$, in order to block the stress-induced increase in blood corticosterone (Haleem et al., 1988). Corticosterone (CORT, Sigma-Aldrich) and finasteride (FIN, Interchim) were dissolved in $300 \mu \mathrm{L}$ sesame oil (VEH) and injected SC. CORT was used either at a physiological $\left(5 \mathrm{mg} \mathrm{kg}^{-1}\right)$ or at a pharmacological dosage $\left(40 \mathrm{mg} \mathrm{kg}^{-1}\right)$. The latter dosages were chosen as they mimic the stressinduced blood corticosterone concentrations observed respectively in naive (Baez et al., 1996; Calvo and Volosin, 2001) and metyrapone-treated rats (Krugers et al., 1998). Finasteride was used at $50 \mathrm{mg} \mathrm{kg}^{-1}$, a dosage that blocks completely the 5- $\alpha$ reductase (Lephart et al., 1996).

\subsection{Variables}

\subsection{1. $T_{\text {abd }}$ and $A_{s}$}

$T_{\text {abd }}$ and $A_{s}$ were assessed with a TA10TA-F40 implantable radiotransmitter and the telemetric signal was acquired using a DataQuest system running on ART-gold software 3.1 


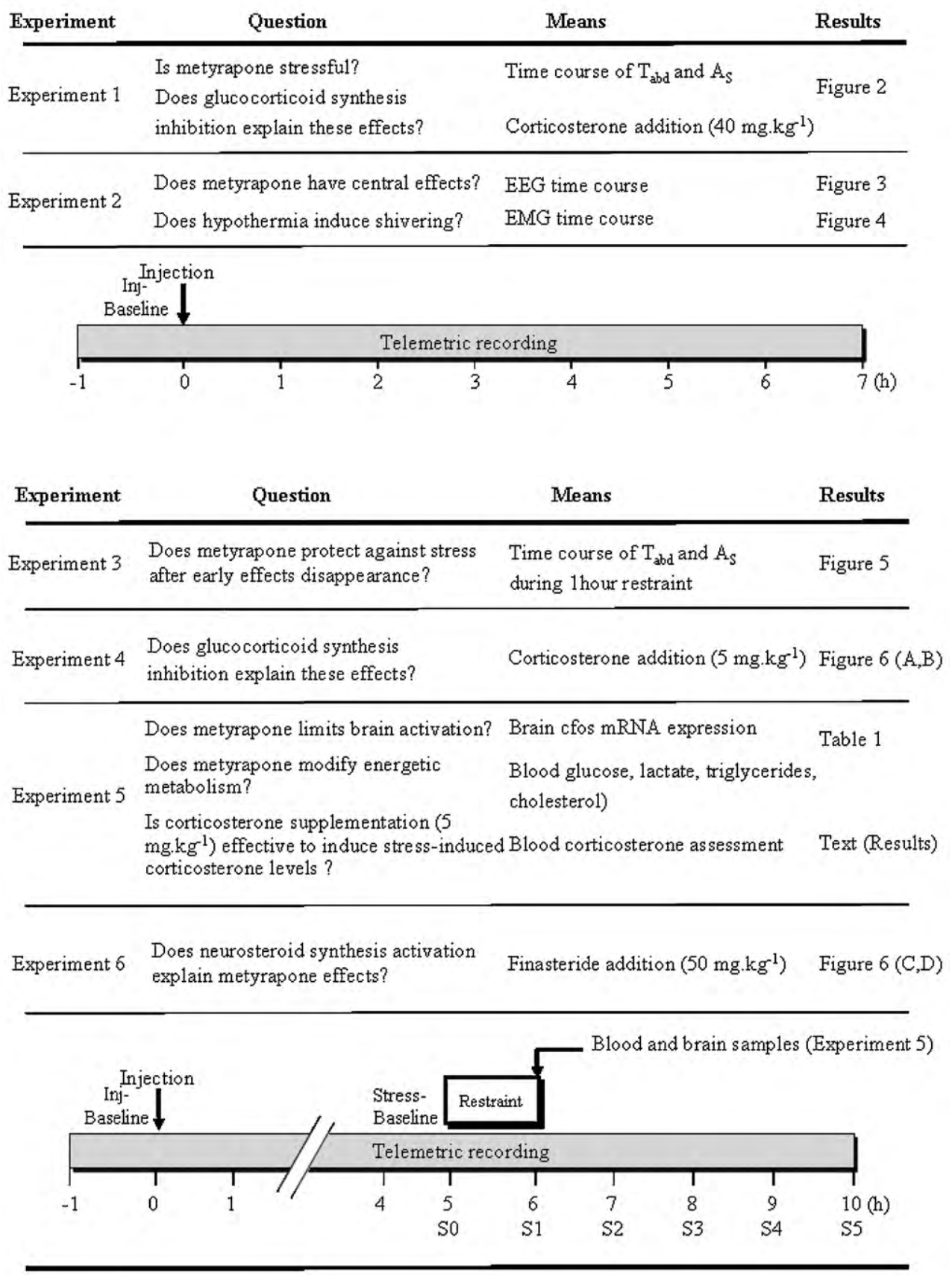

Figure 1 Questions to be answered by each experiment, means used to obtain an answer, related figure or table, and schematic view of experimental procedures. In Experiments 1 and 2, $T_{\mathrm{abd}}, \mathrm{A}_{\mathrm{s}}$, EEG and EMG were measured before and after treatment injection. $T_{\mathrm{abd}}$ and $A_{S}$ were both measured before and after drug injection and restraint in Experiments 3-6. Only data obtained after restraint are shown. Blood and brain samples were collected after stress and related data are presented in Table 1.

(Data Sciences, Saint-Paul, MN, USA). The TA10TA-F40 sensor was implanted into the abdominal cavity under deep anaesthesia (pentobarbital sodium, $60 \mathrm{mg} \mathrm{kg}^{-1}$, IP) according to a procedure described elsewhere (Michel et al., 2007a). As stated previously, the rats were allowed 10 days to recover from surgery.

The $T_{\text {abd }}$ and $A_{s}$ values were measured every 2 min. $A_{S}$ was calculated from variations in the transmitted power signal due to the rat position changes in its home cage. The
$A_{s}$ values $(x)$ were normalized using $z$-scores: $z$-score $(x)=(x-\mu) / \sigma$, standard deviation $(\sigma)$ and mean $(\mu)$ being calculated for each rat during the weekend preceding the experimental day (Chevrier et al., 2006). Weekends measures of $A_{s}$ were thought to represent natural circadian variations, due to the absence of handling. Values in $T_{\mathrm{abd}}$ and $A_{s}$ were averaged in 15-min and $1-\mathrm{h}$ time periods. Baseline was assumed to be the mean value of the hour preceding injection or restraint exposure. Final data were 
calculated as a difference to the relevant baseline ( $\Delta$ values).

\subsection{Electroencephalogram and electromyogram}

To assess EEG and EMG, the TL10M3-F50-EEE transmitter (Data Sciences) was inserted into a pouch in the interscapular subcutaneous tissue under deep anaesthesia (pentobarbital sodium, $60 \mathrm{mg} \mathrm{kg}^{-1}, \mathrm{IP}$ ). The electrodes maintained by screws were placed in 5 holes drilled in the calvarium: one pair at $2 \mathrm{~mm}$ anterior and $\pm 3 \mathrm{~mm}$ lateral to the bregma; and one pair at $4 \mathrm{~mm}$ posterior and $\pm 2 \mathrm{~mm}$ lateral to the central suture. The reference electrode was placed $10 \mathrm{~mm}$ posterior to the bregma. Electrodes were anchored with dental cement (Dentalon Plus, Heraeus Kulzer, Dormagen, Germany). The EMG electrodes were placed inside the dorsal neck muscle. The rats received antibiotic (Extencilline ${ }^{\mathbb{R}}$, Sanofi-Aventis, $60,000 \mathrm{IU}$ per rat, IP) and anti-inflammatory treatments (Ketofen $3 \mathrm{mg} \mathrm{kg}^{-1}$, IM, Merial, Lyon, France) and were allowed 10 days to recover.

The signal was recorded at a sampling rate of $500 \mathrm{~Hz}$ (EEG) and $100 \mathrm{~Hz}$ (EMG). Data were imported to the Neuroscore software (v1.1.1, Data Science) for spectral analysis of the EEG by Fast-Fourier Transform (FFT) between 0.5 and $50 \mathrm{~Hz}$ with a $1 \mathrm{~Hz}$ resolution (hamming window, 10-s epochs). After artefact removal, data were analyzed according to two methods: (i) values were normalized by $z$-scores using parameters calculated for each rat on the signal assessed during the $2 \mathrm{~h}$ preceding injection. The calculated values were then averaged by 1 -min epochs and plotted using Sigmaplot (Systat Software Inc., San Jose, CA, USA); (ii) values were divided into 8 frequency bands $(\delta: 0.5-4 \mathrm{~Hz} ; \theta: 4-8 \mathrm{~Hz} ; \alpha$ : $8-$ $11 \mathrm{~Hz} ; \sigma: 11-15 \mathrm{~Hz} ; \beta 1: 15-19 \mathrm{~Hz} ; \beta 2: 19-30 \mathrm{~Hz} ; \gamma 1: 30-$ $35 \mathrm{~Hz}$ and $\gamma 2: 35-50 \mathrm{~Hz}$ ) and expressed as percent of total spectral power $(0-50 \mathrm{~Hz})$. The EMG was averaged in $15-\mathrm{min}$ epochs and expressed as root mean square of the activity (RMS).

\subsection{Blood variables assessment}

Plasma corticosterone concentration was analyzed using specific radioimmunoassay kits $\left({ }^{125}\right.$ I RIA kit, DPC France, La Garenne Colombes, France). Plasma glucose, lactate, triglycerides and cholesterol were assayed on a Hitachi 912 Analyser (Roche Diagnostics, Meylan, France) with the colorimetric method using Roche ${ }^{T M}$ reagents (Roche Diagnostics). Analyses were performed according to the manufacturers' instructions.

\section{6. mRNA quantification by RT-PCR}

The mRNA quantification of c-fos (NM_022197.2), CycA (NM_017101.1), $\quad \beta$-actin (NM_031144.2) and ARBP (NM_022402.1) was done according to previously described methods (Michel et al., 2007a), using the same primers except for ARBP (Barbier et al., 2009). Briefly, the samples were conditioned in RNAlater (Qiagen, Courtaboeuf, France) until RNA extraction using MagNA Pure LC mRNA Isolation Kit II (Roche Applied Science, Mannheim, Germany). Reverse transcription was performed with oligo-dT (Reverse Transcription Core Kit, Eurogentec, Seraing, Belgium). Real-time
PCR was carried out with the LightCycler Fast Start DNA Master SYBR Green kit (Roche Applied Science) with LightCycler (Roche Applied Science). Quantification cycles were assessed using the second derivative maximum method from a pool of cDNA samples as calibrator (Peinnequin et al., 2004), according to the comparative threshold cycle method (Livak and Schmittgen, 2001). Specificity of PCR amplification was verified with the LightCycler melting curve analysis (Peinnequin et al., 2004). The validity of internal control genes (Cyca, $\beta$-actin and ARPB) was checked using geNorm (Vandesompele et al., 2002).

\section{Experimental designs}

Fig. 1 recapitulates the questions to be answered by each experiment, the experimental means that were used and the corresponding figures and tables presenting the results obtained.

\subsection{Experiment 1}

Experiment 1 analyzed (i) whether metyrapone induces stress using $T_{\mathrm{abd}}$ and $A_{s}$ time courses and (ii) whether metyrapone effects are related to glucocorticoid synthesis inhibition using a $40 \mathrm{mg} \mathrm{kg}^{-1}$ corticosterone supplementation. The 43 rats were randomly distributed into 4 groups: saline-vehicle (SAL-VEH, $n=11)$, saline-corticosterone (SAL-CORT, $n=10$ ), metyrapone-vehicle (MET-VEH, $n=11$ ), and metyrapone-corticosterone (MET-CORT, $n=11)$. The rats, previously instrumented with TA10TA-F40 telemetric devices, received the assigned treatment and were left undisturbed for $T_{\text {abd }}$ and $A_{s}$ recordings.

\subsection{Experiment 2}

Experiment 2 investigated (i) whether metyrapone elicits cerebral (central) effects and (ii) whether metyraponeinduced hypothermia triggers shivering through EEG and EMG recordings, respectively. The experiment was performed in 8 rats previously instrumented with TL10M3-F50EEE telemetric devices. After recovery from surgery, each rat received an injection of saline and, 2 days later, another injection of metyrapone. Substances were given $120 \mathrm{~min}$ after lights were turned on and all recordings were made during the light period.

\subsection{Experiment 3}

Experiment 3 aimed at assessing the protective effect of metyrapone against stressor exposure by analyzing the time course of $T_{\mathrm{abd}}$ and $A_{s}$ during and after a 1-h restraint exposure carried out after normalization of metyrapone-induced $T_{\text {abd }}$ and $A_{s}$ alterations. The 51 rats were randomly distributed into saline/rest $(S A L-R, n=12)$, saline/stress $(S A L-S$, $n=13)$, metyrapone/rest (MET-R, $n=13)$ and metyrapone/stress (MET-S, $n=13$ ). The rats, previously instrumented with TA10TA-F40 telemetric devices, received the assigned pharmacological treatment and were then left undisturbed during $5 \mathrm{~h}$. At this time, the rats belonging to stress groups were restrained during $1 \mathrm{~h}$, then released and left again undisturbed. The rats belonging to rest groups remained undisturbed in their home cage throughout. 


\subsection{Experiment 4}

Experiment 4 evaluated the involvement of glucocorticoid synthesis inhibition in the reduction of stress-induced physiological response after metyrapone. The time course of $T_{\text {abd }}$ and $A_{s}$ was studied in the same way as in Experiment 3. However, a $5 \mathrm{mg} \mathrm{kg}^{-1}$ corticosterone supplementation was administered concomitantly to metyrapone to obtain a corticosteroneclamp condition. The 43 rats were randomly affected to saline-vehicle (SAL-VEH, $n=11)$, saline-corticosterone (SALCORT, $n=11)$, metyrapone-vehicle (MET-VEH, $n=10)$ and metyrapone-corticosterone (MET-CORT, $n=11$ ). The rats, previously instrumented with TA10TA-F40 telemetric devices, received the assigned pharmacological treatment. They were left undisturbed during $5 \mathrm{~h}$, then restrained during $1 \mathrm{~h}$, and lastly released to remain undisturbed again.

\subsection{Experiment 5}

Experiment 5 analyzed (i) whether metyrapone was capable of limiting stress-induced biological responses in the same experimental paradigm as in Experiment 4 and (ii) whether a $5 \mathrm{mg} \mathrm{kg}^{-1}$ corticosterone supplementation was sufficient to obtain stress-like levels of glucocorticoid blood concentration. The 60 rats were randomly distributed into saline/rest (SAL-R, $n=10)$, metyrapone/rest (MET-R, $n=10)$, saline/stress (SAL-S, $n=10)$, metyrapone/stress (MET-S, $n=10)$, metyrapone-corticosterone/stress (MET + CORT-S, $n=10)$ and saline-corticosterone/stress (CORT-S, $n=10$ ). Five hours after treatment, the rats were exposed to a 1 -h restraint (stress groups) or were left undisturbed in their home cage (rest groups). Immediately after restraint, the rats were quickly anaesthetized with $100 \% \quad \mathrm{O}_{2}$ ventilation containing $4 \%$ halothane (Laboratoire Belmont, Paris, France). Blood samples were placed in tubes containing lithium heparinate (Sarstedt, Marnay, France). Plasma was sampled after centrifugation and stored at $-80{ }^{\circ} \mathrm{C}$ until assessment of blood variables. Prefrontal cortex and hippocampus were dissected and placed into RNAlater (Ambion, Courtaboeuf, France). These samples were maintained at $4{ }^{\circ} \mathrm{C}$ during $24 \mathrm{~h}$ then stored at $-20^{\circ} \mathrm{C}$ until mRNA quantification by RT-PCR.

\subsection{Experiment 6}

Experiment 6 evaluated the role of THDOC in the metyrapone-induced $T_{\mathrm{abd}}$ and $\mathrm{A}_{\mathrm{s}}$ changes using finasteride co-treatment. The 45 rats were randomly assigned to saline-vehicle (SAL-VEH, $n=12)$, saline-finasteride (SAL-FIN, $n=11)$, metyrapone-vehicle (MET-VEH, $n=11)$ and metyraponefinasteride (MET-FIN, $n=11)$. The experimental protocol was strictly similar to that of Experiment 4.

\subsection{Statistical analysis}

Statistical analysis was performed with Statistica v7.1 (StaSoft-France, Maisons-Alfort, France). Comparisons were done by two-factor analysis of variance (ANOVA). The $T_{\text {abd }}$ and $A_{s}$ time courses were analyzed using ANOVA for repeated measures with factor effects. If necessary, post hoc tests were done using Bonferroni tests. Values are presented as means \pm standard error of the mean (SEM).

\section{Results}

\subsection{Experiment 1}

During the baseline before injection, slight statistical differences (MET, ns; CORT, ns; interaction $p<0.01$ ) were observed for $T_{\text {abd }}$ (SAL-VEH: $37.0 \pm 0.1^{\circ} \mathrm{C}$; MET-VEH: $37.1 \pm 0.1{ }^{\circ} \mathrm{C}$; SAL-CORT: $37.2 \pm 0.1{ }^{\circ} \mathrm{C}$ and MET-CORT: $\left.36.9 \pm 0.1{ }^{\circ} \mathrm{C}\right)$, but not for $A_{S}(S A L-V E H:-0.2 \pm 0.1$; METVEH: $-0.1 \pm 0.1$; SAL-CORT: $-0.1 \pm 0.1$ and MET-CORT: $-0.2 \pm 0.1)$.

Saline injection induced a strong hyperthermia (Fig. 2A). In rats receiving metyrapone, the hyperthermia was blocked and was followed by a 3-h hypothermia (Fig. 2A; MET, $p<0.001$; and MET $\times$ repetition, $p<0.001)$. Corticosterone treatment did not modify $T_{\text {abd }}$ time course with or without metyrapone co-treatment. Saline injection induced also an immediate increase in $A_{S}$ (Fig. 2B), which was not observed after metyrapone. However, $A_{s}$ was enhanced $2 \mathrm{~h}$ after metyrapone injection (MET, ns; MET $\times$ repetition, $p<0.001)$. Co-administration
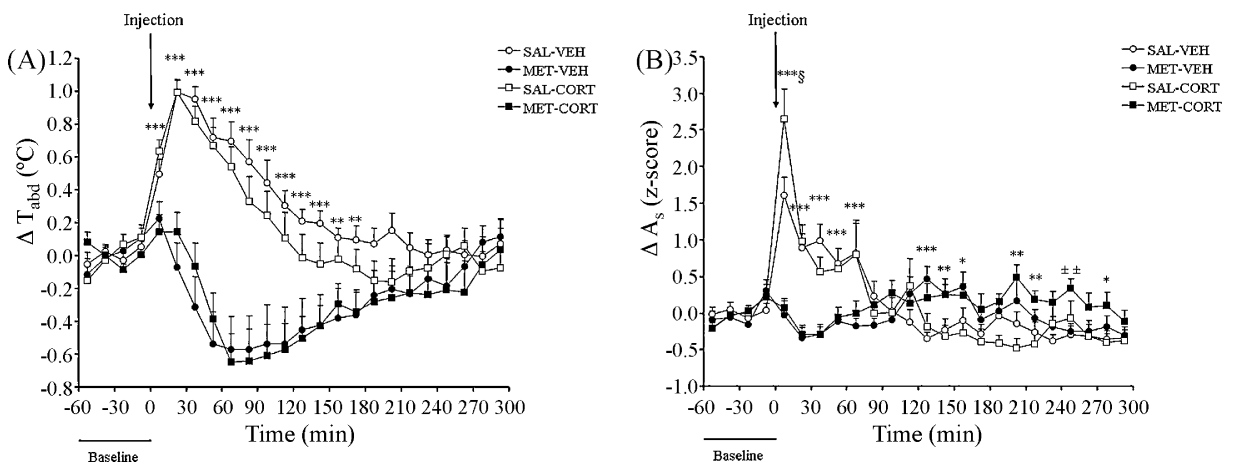

Figure 2 Effect of acute administration of $150 \mathrm{mg} \mathrm{kg}^{-1}$ metyrapone IP and $40 \mathrm{mg} \mathrm{kg}^{-1}$ corticosterone SC on relative variations of abdominal temperature $\left(\mathrm{A}, \Delta T_{\text {abd }}\right.$ expressed in $\left.{ }^{\circ} \mathrm{C}\right)$ and locomotor activity $\left(\mathrm{B}, \Delta \mathrm{A}_{\mathrm{s}}, \mathrm{z}\right.$-score). According to their experimental group, the rats received saline and sesame oil (SAL-VEH, $n=11)$, metyrapone and sesame oil (MET-VEH, $n=11)$, saline and corticosterone (SALCORT, $n=11$ ) or metyrapone and corticosterone (MET-CORT, $n=10)$. Comparisons between groups used two ways factorial ANOVA and significant differences are indicated as follows: MET effect: ${ }^{* *} p<0.01$ and ${ }^{* * *} p<0.001$; CORT effect: ${ }^{ \pm \pm} p<0.01$ and interaction between MET and CORT effects: ${ }^{s} p<0.05$. Data are expressed as means \pm SEM. 

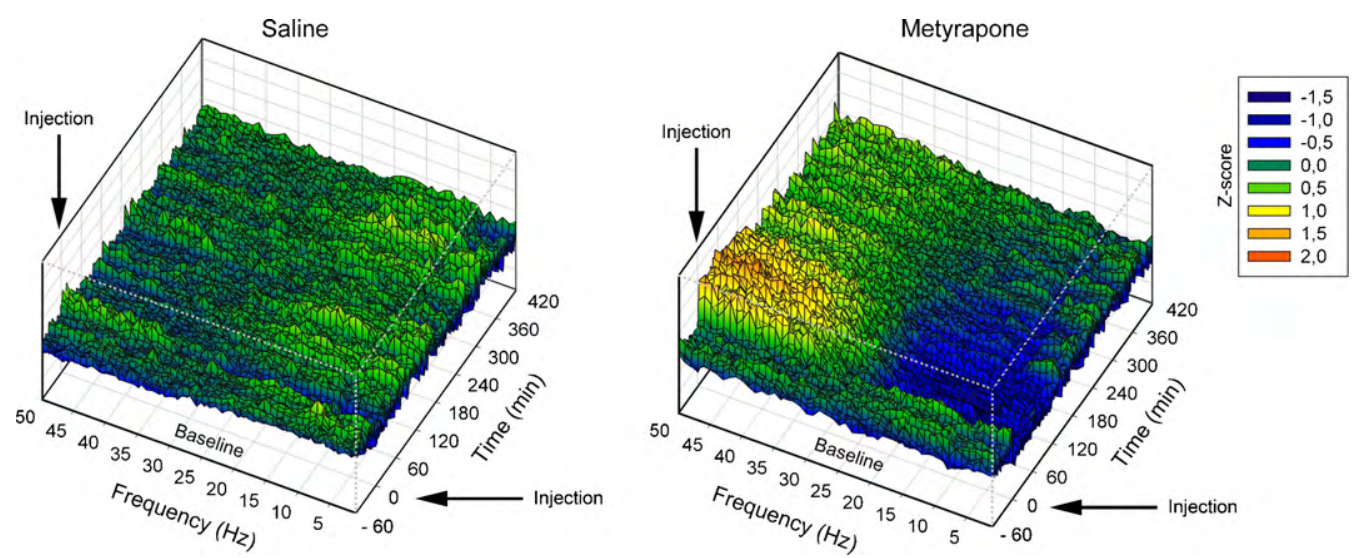

Figure 3 Change in EEG spectral profile after metyrapone administration. Eight animals received saline injection first (saline IP) and metyrapone 2 days later ( $150 \mathrm{mg} \mathrm{kg}^{-1}$ metyrapone IP). Spectral powers between 0.5 and $50 \mathrm{~Hz}$ were analyzed with a 1 - $\mathrm{Hz}$ resolution. The EEG spectral data were transformed into $z$-scores and averaged by 1 -min epochs. Then, $z$-score data were averaged over 8 animals and color-coded.

of corticosterone did not affect $A_{s}$ time course after saline or metyrapone, although it amplified the increase in $A_{S}$ during the first $15 \mathrm{~min}$ after saline injection $(p<0.05)$. During the 5 th hour post-injection, $T_{\text {abd }}$ and $A_{S}$ resumed pre-injection values and SAL-VEH and MET-VEH groups did not differ. This time period was thus selected as the reference period (stressbaseline) for the evaluation of metyrapone effects on stress reaction.

\subsection{Experiment 2}

Saline injection induced a 5-min decrease in the EEG spectral power in frequency bands between 0.5 and $25 \mathrm{~Hz}$ and a slight increase between 35 and $50 \mathrm{~Hz}$ (Fig. 3). No change was detected thereafter. Compared to saline, metyrapone modified the time course of EEG spectral power profoundly. It decreased $\alpha$ band relative power but did not affect the relative power of the $\delta, \theta, \sigma$ and $\beta 1$ bands. The main effect resided in the large increase that occurred in the $\gamma 1, \gamma 2$ bands and in the $\beta 2$ band. The effects of metyrapone lasted $2 \mathrm{~h}$ after injection for $\alpha, \beta 2$ and $\gamma 1$ frequency bands and $3 \mathrm{~h}$ for the $\gamma 2$ frequency band (data not shown). Concomitantly, metyrapone induced an increase in EMG activity, especially during the second hour following injection (Fig. 4; MET, ns and MET $\times$ repetition, $p<0.05)$.

\subsection{Experiment 3}

Before restraint stress, as in Experiment 1, saline injection triggered hyperthermia. Metyrapone administration blocked this stress-induced hyperthermia, and induced a subsequent hypothermia. The stress-induced increase in $A_{s}$ observed in saline rats was also blocked by metyrapone (data not shown).

During stress-baseline, no difference was observed between groups for $T_{\text {abd }}$ (SAL-R: $37.0 \pm 0.1{ }^{\circ} \mathrm{C}$; MET-R: $36.7 \pm 0.2^{\circ} \mathrm{C} ; \quad \mathrm{SAL}-\mathrm{S}: \quad 37.0 \pm 0.1{ }^{\circ} \mathrm{C}$ and $\mathrm{MET}-\mathrm{S}$ : $\left.36.8 \pm 0.2^{\circ} \mathrm{C}\right)$ and $A_{S}$ (SAL-R: $-0.2 \pm 0.1 ; \quad M E T-R$ : $0.0 \pm 0.1$; SAL-S: $-0.3 \pm 0.1$ and MET-S: $-0.3 \pm 0.1)$. During restraint, $T_{\text {abd }}$ increased sharply in saline rats (Fig. 5A; stress, ns; and stress $\times$ repetition, $p<0.001$ ) and the stressinduced hyperthermia was blunted by metyrapone. In the resting condition, $T_{\text {abd }}$ levels remained higher in metyrapone than in saline rats (MET, ns; MET $\times$ repetition, $p<0.001$ and MET $\times$ stress $\times$ repetition, $p<0.001)$.

After restraint release, saline rats exhibited a sharp increase in $A_{s}$ (Fig. 5B; stress, ns; and stress $\times$ repetition, $p<0.001)$. Metyrapone limited the stress-induced increase in $A_{S}$ (MET, ns; MET $\times$ repetition, $p<0.001$ and MET $\times-$ stress $\times$ repetition, $p<0.05)$.

\subsection{Experiment 4}

Similarly to observations made in Experiment 1, hyperthermia and increased $A_{s}$ were observed after saline injection, while hypothermia and a reduction in $A_{s}$ followed metyrapone injection. Corticosterone administration did not modify the concomitant $T_{\text {abd }}$ or $A_{s}$ time courses in saline and metyrapone rats (data not shown).

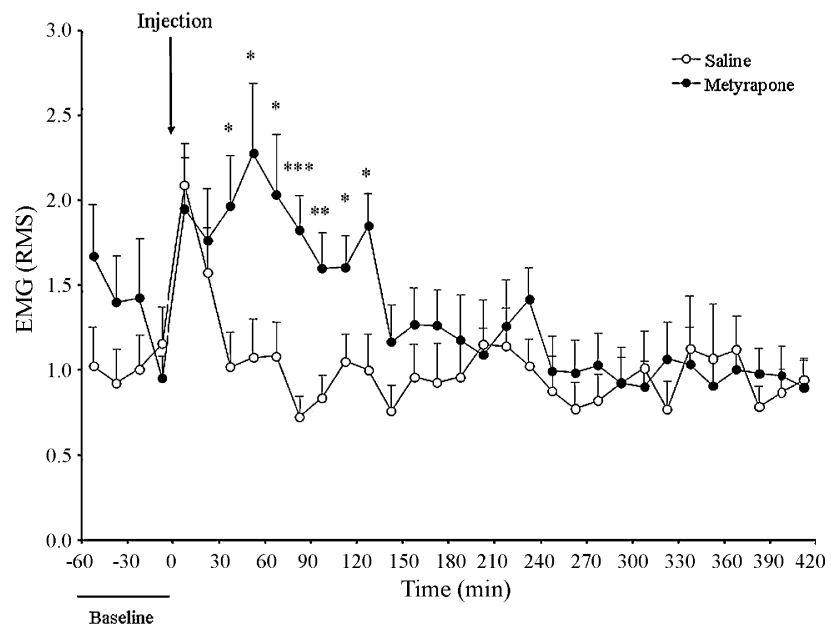

Figure 4 Changes in EMG after metyrapone administration. Eight animals received saline injection first (saline IP) and metyrapone 2 days later $\left(150 \mathrm{mg} \mathrm{kg}^{-1}\right.$ metyrapone IP). The EMG was expressed as the $10^{5}$ root mean square of the activity (RMS). Comparisons between groups were made through a twoway factorial ANOVA and significant differences are indicated as follows: MET effect: ${ }^{*} p<0.05 ;{ }^{* *} p<0.01$ and ${ }^{* * *} p<0.001$. Data are expressed as means \pm SEM. 

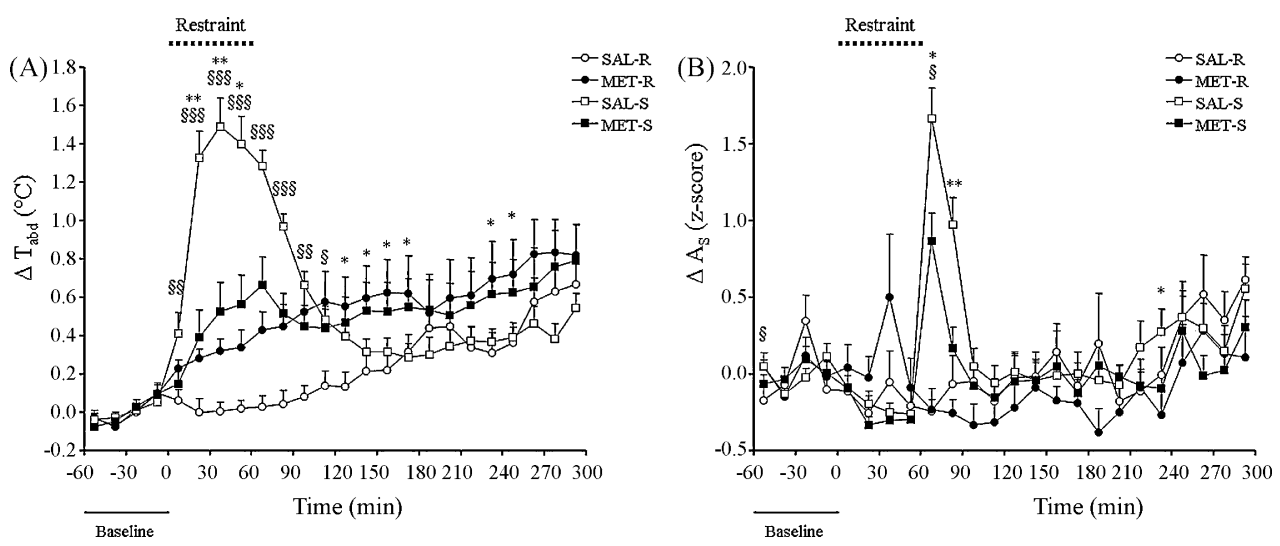

Figure 5 Effect of a 1-h restraint on abdominal temperature $\left(\mathrm{A}, \Delta T_{\mathrm{abd}},{ }^{\circ} \mathrm{C}\right)$ and locomotor activity $\left(\mathrm{B}, \Delta \mathrm{A}_{\mathrm{s}}, \mathrm{z}\right.$-score $)$ in rats treated $5 \mathrm{~h}$ earlier with either $150 \mathrm{mg} \mathrm{kg}^{-1}$ metyrapone IP or saline IP. The rats were conditioned as follows: saline and rest $(S A L-R, n=12)$, metyrapone and rest (MET-R, $n=13$ ), saline and stress (SAL-S, $n=13$ ) or metyrapone and stress (MET $-\mathrm{S}, n=13)$. Restraint duration is represented by the dotted line. Comparisons between groups used two ways factorial ANOVA and significant differences are indicated as follows: MET effect: ${ }^{*} p<0.05$ and ${ }^{* *} p<0.01$; interactions between MET and stress effects: ${ }^{\S} p<0.05 ;{ }^{\S \S} p<0.01$ and ${ }^{\S \S \S} p<0.001$. Data are expressed as means \pm SEM.

During stress-baseline, compared to saline rats, metyrapone rats exhibited higher $T_{\text {abd }}$ (SAL-VEH: $37.0 \pm 0.1{ }^{\circ} \mathrm{C}$; MET-VEH: $37.2 \pm 0.1^{\circ} \mathrm{C}$; SAL-CORT: $36.8 \pm 0.1{ }^{\circ} \mathrm{C}$ and MET-CORT: $\left.37.2 \pm 0.1{ }^{\circ} \mathrm{C}, \mathrm{MET}, \quad p<0.01\right)$ and $\mathrm{A}_{S}(\mathrm{SAL}-$ VEH: $\quad-0.3 \pm 0.1 ; \quad$ MET-VEH: $-0.2 \pm 0.1 ; \quad$ SAL-CORT: $-0.4 \pm 0.1$ and MET-CORT: $0.0 \pm 0.1$, MET, $p<0.05$; MET $\times$ CORT, $p<0.05)$. Metyrapone reduced stress-induced hyperthermia (Fig. 6A; MET, $p<0.01$; and MET $\times$ repetition, $p<0.001$ ) and blunted the increase in $A_{S}$ (Fig. 6B; MET, $p<0.01$; and MET $\times$ repetition, $p<0.001)$. Corticosterone supplementation did not change $T_{\text {abd }}$ and $A_{S}$ time courses in saline and metyrapone rats.

\subsection{Experiment 5}

Metyrapone did not modify blood corticosterone levels in resting condition (SAL-R: $125.9 \pm 26.7 \mathrm{ng} \mathrm{ml}^{-1}, M E T-\mathrm{R}$ : $123.1 \pm 16.0 \mathrm{ng} \mathrm{m}^{-1}$ ). Restraint induced an increase in corticosterone levels that was blunted by metyrapone (SAL-S: $476.2 \pm 15.3 \mathrm{ng} \mathrm{ml}^{-1}$, MET-S: $186.4 \pm 8.0 \mathrm{ng} \mathrm{ml}^{-1}$, MET, $p<0.001$; stress, $p<0.001$; MET $\times$ stress, $p<0.001$ ).
In stressed rats, corticosterone supplementation limited the stress-induced increase in plasma corticosterone in saline rats (SAL-S: $476.2 \pm 15.3 \mathrm{ng} \mathrm{ml}^{-1}, \mathrm{SAL}+\mathrm{CORT}-\mathrm{S}: 358.3$ $\pm 39.8 \mathrm{ng} \mathrm{ml}^{-1}$; SAL-S vs. SAL + CORT-S: $\left.p<0.01\right)$. Corticosterone addition had the opposite effect in metyraponetreated rats (MET-S: $186.4 \pm 8.0 \mathrm{ng} \mathrm{ml}^{-1}$, MET + CORT-S: $284.6 \pm 19.9 \mathrm{ng} \mathrm{m}^{-1} ; \quad$ MET, $\quad p<0.001 ; \quad$ CORT, ns; CORT $\times$ MET, $\quad p<0.001 ; \quad M E T-S$ vs. MET + CORT $-\mathrm{S}:$ $p<0.05)$.

Metyrapone did not alter resting levels of cortical and hippocampal c-fos mRNA expressions. c-fos mRNA expression increased after restraint in the frontal cortex (Table 1; stress, $p<0.001$ ) and hippocampus (stress, $p<0.01$ ). This reaction was not affected by prior metyrapone treatment (MET, ns; MET $\times$ stress, ns).

Plasma glucose level was increased by stress and metyrapone, without any interaction between the two conditions (Table 1 ; MET, $p<0.001$; stress, $p<0.001$; MET $\times$ stress, ns). Metyrapone modified energetic metabolism as shown by the increase in plasma triglycerides (MET, $p<0.05)$ and the slight decrease in plasma cholesterol concentrations (MET,

Table 1 Effect of metyrapone and stress on glucose $\left(\mathrm{mMol} \mathrm{L}^{-1}\right)$, lactate $\left(\mathrm{mMol} \mathrm{L}^{-1}\right)$ triglycerides $\left(\mathrm{mMol} \mathrm{L}^{-1}\right)$ and cholesterol ( $\left.\mathrm{mMol} \mathrm{L}{ }^{-1}\right)$, and frontal cortex and hippocampus c-fos mRNA (a.u.). The animals received either saline and were stressed (SAL-S, $n=10$ ) or rested (SAL-R, $n=10$ ) or metyrapone and were stressed (MET-S, $n=10$ ) or rested (MET-R, $n=10$. The 1 -h restraint was applied $5 \mathrm{~h}$ after treatment injection. Blood and brain samples were collected immediately at the end of restraint. The effects of metyrapone and stress were analyzed using a two-way ANOVA. Statistical differences are expressed in the first column with MET effect: ${ }^{*} p<0.05 ;{ }^{* * *} p<0.001$ and stress effect: ${ }^{ \pm \pm} p<0.01 ;{ }^{ \pm \pm \pm} p<0.001$. Data are expressed as means \pm SEM.

\begin{tabular}{|c|c|c|c|c|c|}
\hline & $p$ & SAL-R & MET-R & SAL-S & MET-S \\
\hline Frontal cortex c-fos & \pm \pm \pm & $0.4 \pm 0.1$ & $0.4 \pm 0.1$ & $1.3 \pm 0.3$ & $1.0 \pm 0.1$ \\
\hline Hippocampus c-fos & \pm \pm & $0.6 \pm 0.1$ & $0.6 \pm 0.2$ & $1.1 \pm 0.1$ & $0.9 \pm 0.1$ \\
\hline Glucose & $\begin{array}{l}* * * \\
\pm \pm \pm\end{array}$ & $10.9 \pm 0.3$ & $12.0 \pm 0.3$ & $12.1 \pm 0.3$ & $13.1 \pm 0.3$ \\
\hline Lactate & & $2.3 \pm 0.2$ & $2.3 \pm 0.2$ & $2.4 \pm 0.4$ & $2.4 \pm 0.2$ \\
\hline Triglycerides & * & $1.2 \pm 0.1$ & $1.6 \pm 0.2$ & $1.1 \pm 0.1$ & $1.6 \pm 0.2$ \\
\hline Cholesterol & & $1.8 \pm 0.1$ & $1.6 \pm 0.1$ & $1.7 \pm 0.1$ & $1.6 \pm 0.1$ \\
\hline
\end{tabular}



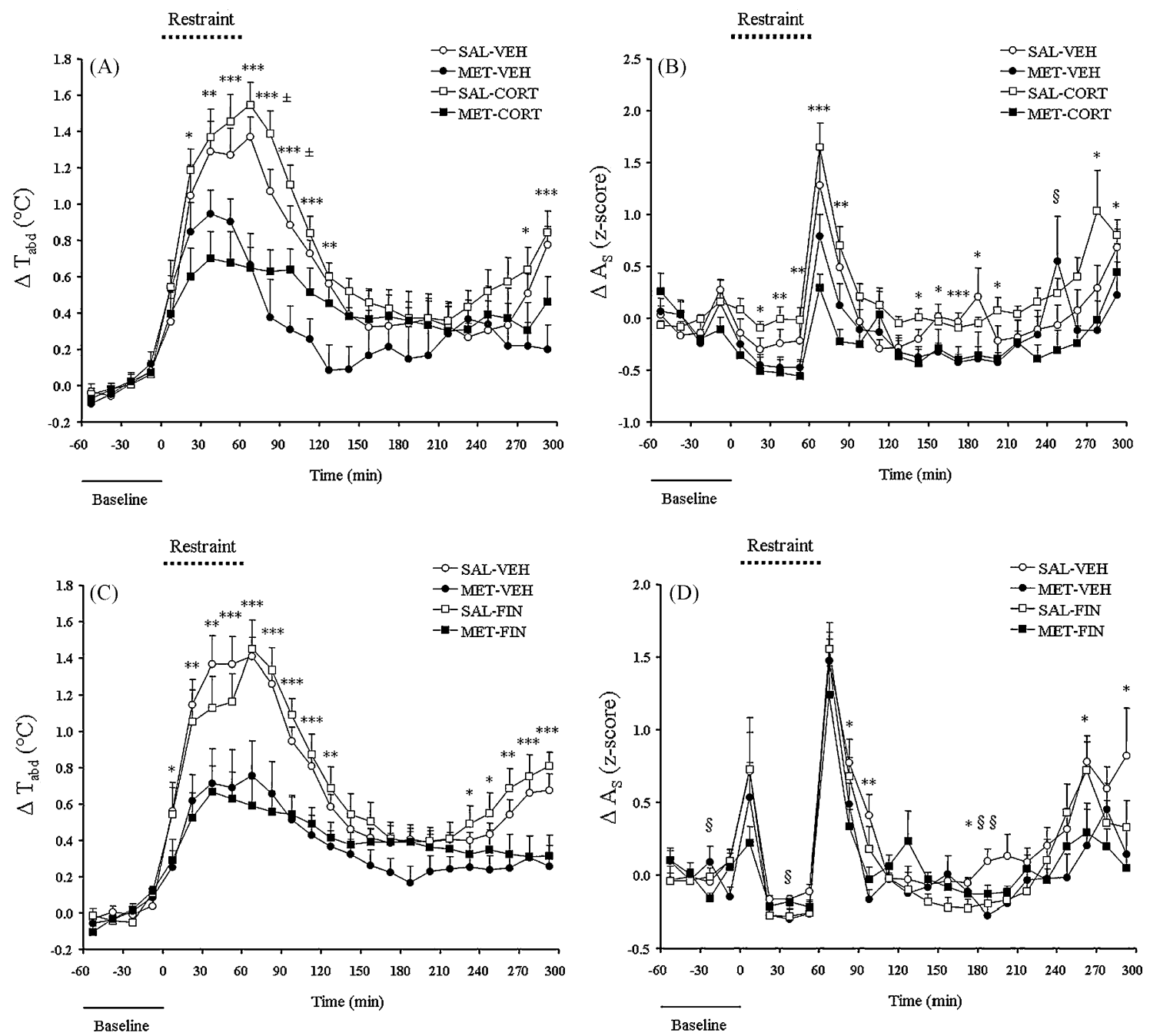

Figure 6 (A and B) Effect of a 1-h restraint on abdominal temperature $\left(\mathrm{A}, \Delta T_{\mathrm{abd}},{ }^{\circ} \mathrm{C}\right)$ and locomotor activity $(\mathrm{B}, \Delta \mathrm{As}, \mathrm{z}$-score) in rats treated $5 \mathrm{~h}$ earlier with $150 \mathrm{mg} \mathrm{kg}^{-1}$ metyrapone IP and $5 \mathrm{mg} \mathrm{kg}^{-1}$ corticosterone $\mathrm{SC}$. According to their experimental group, the rats received saline and sesame oil (SAL-VEH, $n=11)$, saline and corticosterone (SAL-CORT, $n=11)$, metyrapone and sesame oil (METVEH, $n=10$ ) or both metyrapone and corticosterone (MET-CORT, $n=11$ ). (C and D) Effect of a 1-h restraint on body temperature (C, $\Delta T_{\text {abd }},{ }^{\circ} \mathrm{C}$ ) and locomotor activity $\left(\mathrm{D}, \Delta \mathrm{A}_{\mathrm{s}}, \mathrm{z}\right.$-score) in rats treated $5 \mathrm{~h}$ earlier with $150 \mathrm{mg} \mathrm{kg}^{-1} \mathrm{metyrapone} \mathrm{IP} \mathrm{and/or} 50 \mathrm{mg} \mathrm{kg}^{-1}$ finasteride SC. According to their experimental group, the rats received saline and sesame oil (SAL-VEH, $n=12)$, saline and finasteride (SAL-FIN, $n=11)$, metyrapone and sesame oil (MET-VEH, $n=11)$ or both metyrapone and finasteride $(M E T-F I N, n=11)$. All the rats were restrained. Restraint duration is represented by the dotted line. Comparisons between treatment groups were made through a two-way factorial ANOVA and significant differences are indicated as MET effect: ${ }^{*} p<0.05 ;{ }^{* *} p<0.01{ }^{* * *} p<0.001$; CORT effect: ${ }^{ \pm} p<0.05$; interactions between MET and CORT or FIN: ${ }^{\S} p<0.05$ and ${ }^{\S \S} p<0.01$. Data are expressed as means \pm SEM.

$p=0.09$ ). Stress was ineffective on these variables (stress, ns; MET $\times$ stress, ns).

\subsection{Experiment 6}

Similarly to previous observations on immediate effects, metyrapone induced hypothermia and blocked the increase in $A_{s}$ observed immediately after injection (data not shown). Finasteride co-treatment did not alter the concomitant $T_{\text {abd }}$ and $A_{s}$ time courses in saline- and metyrapone-treated rats (data not shown).

During stress-baseline, metyrapone rats showed higher $T_{\text {abd }}$ than saline rats (SAL-VEH: $37.0 \pm 0.1{ }^{\circ} \mathrm{C}$; MET-VEH: $37.4 \pm 0.1{ }^{\circ} \mathrm{C} ; \quad$ SAL-FIN: $\quad 36.9 \pm 0.1{ }^{\circ} \mathrm{C}$ and MET-FIN: $\left.37.3 \pm 0.1{ }^{\circ} \mathrm{C}, \mathrm{MET}, p<0.001\right)$. However, $\mathrm{A}_{s}$ remained similar
(SAL-VEH: $-0.4 \pm 0.1 ;$ MET-VEH: $-0.3 \pm 0.1 ;$ SAL-FIN: $-0.3 \pm 0.1$; MET-FIN: $-0.3 \pm 0.1$, ns). During restraint, metyrapone-treated rats exhibited a reduced hyperthermia compared to saline-treated rats (Fig. 6C; MET, $p<0.001$; MET $\times$ repetition, $p<0.001)$. Finasteride did not change $T_{\text {abd }}$ time course in both saline and metyrapone rats. The increased locomotion observed after restraint in saline rats was reduced by metyrapone (Fig. 6D; MET, $p<0.05$; MET $\times$ repetition, $p<0.001)$. Finasteride did not modify $A_{S}$ time course in both treatment groups.

\section{Discussion}

The present investigations demonstrated that metyrapone rapidly induced hypothermia and depressed locomotion 
while triggering cerebral arousal. After dissipation of these immediate effects, metyrapone also reduced the stressinduced hyperthermia and enhanced motor activity. The effects of metyrapone on body core temperature and locomotion were independent from glucocorticoid synthesis inhibition and THDOC synthesis.

\subsection{Immediate effects of metyrapone}

Immediately after saline injection, $T_{\text {abd }}$ and $A_{S}$ increased in relation to the injection-induced stress reaction. Hyperthermia occurs after handling (Briese and de Quijada, 1970; Vinkers et al., 2009), restraint (De Paula et al., 2000), and social (Sgoifo et al., 2002) and predator (Briese and de Quijada, 1970) confrontations. Increased motor activity is also observed after handling, saline injection (Vinkers et al., 2009) and social confrontation (Sgoifo et al., 2002). Both hyperthermia (Monda et al., 1998; Kiyatkin and Wise, 2001) and increased locomotion (Slawinska and Kasicki, 1998) are tightly linked to cerebral activation. These responses are evoked by cerebral injection of CRF (Morimoto et al., 1993) and reduced by anxiolytic substances such as $\mathrm{GABA}_{\mathrm{A}}$ and 5$\mathrm{HT}_{1 \mathrm{~A}}$ receptor agonists (Bouwknecht et al., 2007; Conley and Hutson, 2007; Vinkers et al., 2009). The close relation between stress-induced hyperthermia and brain activation accounts for the opinion that stress-induced hyperthermia represents a model of anxiety (Bouwknecht et al., 2007).

Metyrapone did not allow hyperthermia and increased spontaneous locomotion to occur immediately after injection. It did not only block the stress-induced hyperthermia but also induced a slight hypothermia. This is in agreement with other descriptions reported in rats (Michel et al., 2007b) and guinea pigs (Werner, 1988), but not in mice (Pryce et al., 2003). Hypothermia was not related to the depressed motor activity as both events ran under different time courses. Moreover, hypothermia occurred despite the increased dorsal neck muscle activity that was strictly limited to the duration of hypothermia. It suggests that hypothermia would be limited by shivering (Gordon, 1990). The neuroprotective properties of metyrapone observed in warmed and anesthetized rats (Smith-Swintosky et al., 1996; Krugers et al., 1998, 2000) might be enhanced by its effect on body temperature (Zhao et al., 2007).

Metyrapone also depressed locomotion acutely in agreement with other studies (Halmy et al., 1970; Canini et al., 2009). Metyrapone may have acted at a peripheral level as (i) its effect on locomotion was concomitant to hypothermia and (ii) the decrease in locomotion occurred without any modification in the $\theta$ frequency band, which is closely related to locomotion speed (Whishaw and Vanderwolf, 1971; Oddie and Bland, 1998; Slawinska and Kasicki, 1998). The decreased locomotion was also concomitant to a large increase in relative EEG spectral power in the rapid $\beta 2, \gamma 1$ and $\gamma 2$ frequency bands. Since elevated $\gamma$ activities have been linked to cortical arousal and attentive behavior (Maloney et al., 1997), it may be that metyrapone had an arousing effect. This effect is congruent to other observations reporting that metyrapone administration is followed by an increase in cfos mRNA expression in the PVN (Herman et al., 1992) and a rise in cerebral Fos-like immunostaining (Rotllant et al., 2002). All these observations exclude that the effect of metyrapone on $T_{\text {abd }}$ and $A_{s}$ were a consequence of a sedative effect (Mikics et al., 2004). Arousal is unlikely to be related to hypothermia (Deboer, 1998) since the increase in rapid frequencies occurred quickly after injection, at a time devoid of any hypothermia. This immediate arousal was more probably due to a direct action of metyrapone on the brain. Metyrapone may have modified environmental appraisal as indicated by the decrease in $\alpha$ power which has been related to cognitive performance in mammals (Klimesch, 1999; Basar et al., 2000). Such a hypothesis may explain that, in our animals, metyrapone induced immobility in a safe environment and reduced immobility during exposure to stressor (Baez and Volosin, 1994; Baez et al., 1996; Roozendaal et al., 1996). This hypothesis is also supported by the reduction of subsequent behavioral anxiety (Calvo et al., 1998; Calvo and Volosin, 2001). Further studies are therefore needed to better delineate the original anxiolytic properties of metyrapone.

\subsection{Subsequent effects of metyrapone}

To evaluate whether metyrapone may have modified appraisal to stressor, the rats were submitted to restraint $5 \mathrm{~h}$ after injection. At this time, the immediate effects of metyrapone were extinct. During stress-baseline, no differences were observed between saline- and metyrapone-treated rats regarding $T_{\mathrm{abd}}, \mathrm{A}_{\mathrm{s}}$, EEG power spectra. Moreover, cerebral c-fos mRNA level and plasma corticosterone concentration were similar in both resting treatment groups $1 \mathrm{~h}$ after. As expected, $T_{\text {abd }}$ increased in saline rats immediately after the beginning of restraint, and locomotion was enhanced just after restraint release. Concomitant cerebral activation was suggested by the increase in c-fos mRNA level in the hippocampus and frontal cortex (Senba and Ueyama, 1997; Chowdhury et al., 2000; Herman et al., 2003). The rats were also hyperglycaemic, such as usually observed in stressed fed rats (Selye, 1950; Nonogaki and Iguchi, 1997). Altogether, the above reactions suggest a strong stress response in salinetreated animals. Compared to saline, metyrapone administration induced a lower increase in $T_{\text {abd }}$ and $A_{s}$. Although metyrapone had increased basal blood glycemia, the latter was further increased after stressor exposure. Such an additive effect suggests that metyrapone and stress acted by different pathways and that metyrapone-treated rats were able to mobilize glucose when exposed to a stressor. Moreover, the c-fos mRNA level increase was statistically similar in both treatment groups after restraint. Metyrapone rats may have perceived their challenging environment, although the physiological consequences were different from those observed in saline-treated rats.

\subsection{Mechanisms of action of metyrapone}

The biochemical mechanisms by which metyrapone may have produced these effects deserve discussion. Although metyrapone is known to block glucocorticoid synthesis (Jenkins et al., 1958), a major role of blood glucocorticoids in the blockade of the stress-induced hyperthermia and increased locomotion triggered by metyrapone is unlikely to occur. The following reasons may be proposed: (i) metyrapone did not induce glucocorticoid depletion because the resting blood corticosterone concentration was similar in metyrapone and saline rats $6 \mathrm{~h}$ after injec- 
tion (Experiment 5), at a time at which stress reactivity was blunted (Experiments 3, 4, 6); (ii) corticosterone supplementation at a dosage that mimics stress levels of blood corticosterone failed to modify the time course of $T_{\text {abd }}$ and $A_{S}$ during both the early and the late phases; (iii) a high dose of corticosterone supplementation in metyrapone rats was also unable to modify the $T_{\text {abd }}$ and $A_{s}$ time course (Experiment 1), whereas it increases locomotion in saline rats suggesting treatment efficiency (Sandi et al., 1996). However, the fact that blood glucocorticoid concentration was not related to the previous effects does not rule out a role of glucocorticoid at the cellular level. Metyrapone can modify tissue glucocorticoid concentration by inhibiting specifically $11 \beta$-hydroxysteroid dehydrogenase type 1 (11 $\beta$-HSD1) (Raven et al., 1995). This enzyme, which is widely expressed by neurons, converts inactive 11dehydrocorticosterone into active corticosterone (Yau and Seckl, 2001).

Metyrapone may also act through the HPA axis activation since it increases brain CRF mRNA, arginine vasopressin and ACTH levels (Herman et al., 1992; Rotllant and Armario, 2005). Although CRF may have been implicated in arousal, it does not explain the blunt in $T_{\text {abd }}$ and $A_{S}$ since it produces the opposite effects (Morimoto et al., 1993). The accumulation of DOC (Conte-Devolx et al., 1992; Raven et al., 1996) further converted into the positive $\mathrm{GABA}_{\mathrm{A}}$ receptor modulator THDOC (Paul and Purdy, 1992) is also to be considered. Under GABA stimulation, metyrapone normalized the maximal chloride uptake previously reduced by restraint (Calvo et al., 1998). Such a positive $G_{A B A}$ modulation could account for metyrapone-induced hypothermia and diminished locomotion. However, the blockade of $5 \alpha$-reductase by finasteride, at a dose reducing brain concentration of neurosteroids (Verleye et al., 2005), failed to reverse the effects of metyrapone. Moreover, the metyrapone-induced brain activation suggested by EEG activation and cerebral cfos induction (Herman et al., 1992) is not in accordance with such a mechanism. Therefore, metyrapone did not act through neurosteroid production.

Alternatively, metyrapone may act by modulating brain neurotransmission. Metyrapone is known to inhibit monoamine oxidase (MAO) and catechol-o-methyl transferase (COMT) (Parvez and Parvez, 1973). It may therefore enhance noradrenaline and dopamine neurotransmission. However, COMT and MAO inhibitors are known to rather trigger hyperthermia and enhanced motor activity (Feldberg and Lang, 1970; Ashkenazi et al., 1983; Rivas et al., 1999). Metyrapone can also modify serotonin neurotransmission by upregulating serotonin $5-\mathrm{HT}_{1 \mathrm{~A}}$ receptor through its effect on intracellular level of corticosteroid (Lopez et al., 1998). A $5-\mathrm{HT}_{1 \mathrm{~A}}$-related mechanism may explain both its hypothermic and anxiolytic properties (De Vry et al., 2004; Hedlund et al., 2004).

Metyrapone may also simply act through metabolic modifications. Metyrapone may have reduced energetic metabolism as suggested by hypothermia. Actually, metyrapone induces metabolic depression in guinea pigs (Werner, 1988), although not in rats (Ohno and Kuroshima, 1986). The metabolic depression may be explained by an inhibition in glucose utilization (Bruno et al., 1972) and a shift towards lipid utilization, as supported by the decrease in respiratory quotient (Werner, 1988). This hypothesis is congruent with the development of hyperglycemia (Werner, 1988; Rotllant et al., 2002) and the observed increase in plasma triglyceride concentration.

\section{Concluding remarks}

Administration of metyrapone in rats triggered an immediate cerebral activation and a concomitant blockade of the injection-induced hyperthermia and enhanced locomotion. Subsequently, long after these early effects, metyrapone limited the consequences of restraint on body core temperature and locomotion. These effects were not mediated by blood corticosteroid concentration or neurosteroid production. These results shed light on the effect of $\mathrm{P}_{450}$ inhibition on energy metabolism, brain activation and behavior, opening new potential pharmacological opportunities in the fields of stress-induce-anxiety disorders and brain ischemia.

\section{Role of funding source}

This work was supported by the grant no. 06 co016 from the DGA. The DGA had no further role in study design; in the collection, analysis and interpretation of data; in the writing of the report; and in the decision to submit the paper for publication.

\section{Conflicts of interest}

The authors declare that over the past three years André Peinnequin has received compensation from ROCHE DIAGNOSTICS, the manufacturer of the qPCR reagents and devices used in this work. The authors have not other financial or competing interest to declare.

\section{Acknowledgements}

We are indebted to J. Denis, L. Vachez-Colomb and V. Leroux for the corticosterone dosages and $\mathrm{C}$. Mouret for her advice.

\section{References}

Armario, A., Marti, O., Gil, M., 1990. The serum glucose response to acute stress is sensitive to the intensity of the stressor and to the habituation. Psychoneuroendocrinology 15, 341-347.

Ashkenazi, R., Finberg, J.P.M., Youdim, M.B.H., 1983. Behavioural hyperactivity in rats treated with selective monoamine oxidase inhibitors and LM5008, a selective 5-hydroxytryptamine uptake blocker. Br. J. Pharmacol. 79, 765-770.

Baez, M., Siriczman, I., Volosin, M., 1996. Corticosterone is involved in foot shock-induced inactivity in rats. Physiol. Behav. 60, 795801.

Baez, M., Volosin, M., 1994. Corticosterone influences forced swiminduced immobility. Pharmacol. Biochem. Behav. 49, 729-736.

Barbier, L., Diserbo, M., Lamproglou, I., Amourette, C., Peinnequin, A., Fauquette, W., 2009. Repeated stress in combination with pyridostigmine. Part II. Changes in cerebral gene expression. Behav. Brain Res. 197, 292-300.

Basar, E., Basar-Eroglu, C., Karakas, S., Schürmann, M., 2000. Brain oscillations in perception and memory. Int. J. Psychophysiol. 35, 95-124.

Bouwknecht, J.A., Olivier, B., Paylor, R.E., 2007. The stress-induced hyperthermia paradigm as a physiological animal model for 
anxiety: a review of pharmacological and genetic studies in the mouse. Neurosci. Biobehav. Rev. 31, 41-59.

Briese, E., de Quijada, M.G., 1970. Colonic temperature of rats during handling. Acta Physiol. Lat. Am. 2, 97-102.

Bruno, O.D., Metzger, P., Malaisse, W.J., 1972. Inhibitory effect of metyrapone on glucose utilization by brain and muscle and on insulin release by the pancreas. Acta Endocrinol. (Copenh.) 70, 710-718.

Calvo, N., Martijena, I.D., Molina, V.A., Volosin, M., 1998. Metyrapone pretreatement prevents the behavorial and neurochemical sequelae induced by stress. Brain Res. 800, 227-235.

Calvo, N., Volosin, M., 2001. Glucocorticoid and mineralocorticoid receptors are involved in the facilitation of anxiety-like response induced by restraint. Neuroendocrinology 73, 261-271.

Canini, F., Brahimi, S., Drouet, J.-B., Michel, V., Alonso, A., Buguet, A., Cespuglio, R., 2009. Metyrapone decreases locomotion acutely. Neurosci. Lett. 457, 41-44.

Chan, R.K.W., Brown, E.R., Ericsson, A., Kovacs, K.J., Sawchenko, P.E., 1993. A comparison of two immediate-early genes, C-fos and NGFI-B, as markers for functional activation in stress related neuroendocrine circuitry. J. Neurosci. 13, 5126-5138.

Chevrier, C., Bourdon, L., Canini, F., 2006. Cosignaling of adenosine and adenosine triphosphate in hypobaric hypoxia-induced hypothermia. Am. J. Physiol. Regul. Integr. Comp. Physiol. 290, R595-R600.

Chowdhury, G.M.I., Fujioka, T., Nakamura, S., 2000. Induction and adaptation of Fos expression in the rat brain by two types of acute restraint stress. Brain Res. Bull. 52, 171-182.

Conley, R.K., Hutson, P.H., 2007. Effects of acute and chronic treatment with fluoxetine on stress-induced hyperthermia in telemetred rats and mice. Eur. J. Pharmacol. 564, 138-145.

Conte-Devolx, B., Guillaume, V., Boudouresque, F., Graziani, N., Magnan, E., Grino, M., Emperaire, N., Nahoul, K., Cataldi, M., Oliver, C., 1992. Effects of metyrapone infusion on corticotrophin-releasing factor and arginine vasopressin secretion into the hypophysal portal blood of conscious, unrestrained rams. Acta Endocrinol. (Copenh.) 125, 435-440.

De Paula, D., Steiner, A.A., Branco, L.G.S., 2000. The nitric oxide pathway is an important modulator of stress-induced fever in rats. Physiol. Behav. 70, 505-511.

De Vry, J., Schreiber, R., Melon, C., Dalmus, M., Jentzsch, K.R., 2004. $5-\mathrm{HT}_{1 \mathrm{~A}}$ receptors are differentially involved in the anxiolytic- and antidepressant-like effects of 8-OH-DPAT and fluoxetine in the rat. Eur. Neuropsychopharmacol. 14, 487-495.

Deboer, T., 1998. Brain temperature dependent changes in the electroencephalogram power spectrum. J. Sleep Res. 7, 254262.

Feldberg, W., Lang, W.J., 1970. Effects of monoamine oxidase inhibitors and amphetamine on hypothermia produced by halotane. Br. J. Pharmacol. 38, 181-191.

Gordon, C.J., 1990. Thermal biology of the laboratory rat. Physiol. Behav. 47, 963-991.

Haleem, D.J., Kennet, G., Curzon, G., 1988. Adaptation of female rats to stress: shift to male pattern by inhibition of corticosterone synthesis. Brain Res. 458, 339-347.

Halmy, L., Bohus, B., Frey, Z., Endroczi, E., 1970. Direct metyrapone effect on the central nervous system. Endokrinologie 57, 139141.

Healy, D.G., Harkin, A., Cryan, J.F., Kelly, J.P., Leonard, B.E., 1999. Metyrapone displays antidepressant-like properties in preclinical paradigms. Psychopharmacology (Berl.) 145, 303-308.

Hedlund, P.B., Kelly, L., Mazur, C., Lovenberg, T., Sutcliffe, J.G., Bonaventure, P., 2004. 8-OH-DPAT acts on both 5- $\mathrm{HT}_{1 \mathrm{~A}}$ and $5-\mathrm{HT}_{7}$ receptors to induce hypothermia in rodents. Eur. J. Pharmacol. 487, 125-132.

Herman, J.P., Figueiredo, H., Mueller, N.K., Ulrich-Lai, Y., Ostrander, M.M., Choi, D.C., Cullinam, W.E., 2003. Central mechanisms of stress integration: hierarchical circuitry controlling hypotha- lamo-pituitary-adrenocortical responsiveness. Front. Neuroendocrinol. 24, 151-180.

Herman, J.P., Schafer, M.K.H., Thompson, R.C., Watson, S.J., 1992. Rapid regulation of corticotropin-releasing hormone gene transcription in vivo. Mol. Endocrinol. 6, 1061-1069.

Jenkins, J.S., Meakin, J.W., Nelson, D.H., Thorn, G.W., 1958. Inhibition of adrenal steroid 11-oxygenation in the dog. Science 128 $478-480$.

Kiyatkin, E.A., Wise, R.A., 2001. Striatal hyperthermia associated with arousal: intracranial thermorecordings in behaving rats. Brain Res. 918, 141-152.

Klimesch, W., 1999. EEG alpha and theta oscillations reflect cognitive and memory performance: a review and analysis. Brain Res. Rev. 29, 169-195.

Krugers, H.J., Kemper, R.H., Korf, J., Ter Horst, G.J., Knollema, S., 1998. Metyrapone reduces rat brain damage and seizures after hypoxia-ischemia: an effect independent of modulation of plasma corticosterone levels? J. Cerebr. Blood Flow Metab. $18,386-390$

Krugers, H.J., Maslam, S., Korf, J., Joëls, M., 2000. The corticosterone synthesis inhibitor metyrapone prevents hypoxia/ischemiainduced loss of synaptic function in the rat hippocampus. Stroke 31, 1162-1172.

Lephart, E.D., Ladle, D.R., Jacobson, N.A., Rhees, R.W., 1996. Inhibition of brain $5 \alpha$-reductase in pregnant rats: effects on enzymatic and behavioral activity. Brain Res. 739, 356360 .

Livak, K.J., Schmittgen, T.D., 2001. Analysis of relative gene expression data using real-time quantitative PCR and the $2^{-\Delta \Delta C} T$ method. Methods 25, 402-408.

Lopez, J.F., Chalmers, D.T., Little, K.Y., Watson, S.J., 1998. Regulation of serotonin ${ }_{1 \mathrm{~A}}$, glucocorticoid, and mineralocorticoid receptor in rat and human hippocampus: implications for the neurobiology of depression. Biol. Psychiatry 43, 547-573.

Maloney, K.J., Cape, E.G., Gotman, J., Jones, B.E., 1997. Highfrequency $\gamma$ electroencephalogram activity in association with sleep-wake states and spontaneous behaviours in the rat. Neuroscience $76,541-555$.

Marinelli, M., Rougé-Pont, F., De Jesus-Oliveira, C., Le Moal, M., Piazza, P.V., 1997. Acute blockade of corticosterone secretion decreases the psychomotor stimulant effects of cocaine. Neuropsychopharmacology 16, 156-161.

Michel, V., Peinnequin, A., Alonso, A., Buguet, A., Cespuglio, R., Canini, F., 2007a. Decreased heat tolerance is associated with hypothalamo-pituitary-adrenocortical axis impairment. Neuroscience 147, 522-531.

Michel, V., Peinnequin, A., Alonso, A., Buguet, A., Cespuglio, R., Canini, F., 2007b. Effect of glucocorticoid depletion on heatinduced Hsp70, IL-1 $\beta$ and TNF- $\alpha$ gene expression. Brain Res. 1164, 63-71.

Mikics, E., Barsy, B., Barsvari, B., Haller, J., 2005. Behavioral specificity of non-genomic glucocorticoid effect in rats: effects on risk assessment in the elevated plus-maze and the open-field. Horm. Behav. 48, 152-162.

Mikics, E., Kruk, M.R., Haller, J., 2004. Genomic and non-genomic effects of glucocorticoids on aggressive behavior in male rats. Psychoneuroendocrinology 29, 618-635.

Monda, M., Sullo, A., DeLuca, V., Viggiano, A., 1998. Procaine injection into the paraventricular nucleus reduces sympathetic and thermogenic activation induced by frontal cortex stimulation in the rat. Brain Res. Bull. 47, 657-662.

Morimoto, A., Nakamori, T., Morimoto, K., Tan, N., Murakami, N., 1993. The central role of corticotrophin-releasing factor (CRF41 ) in psychological stress in rats. J. Physiol. (Lond.) 460, 221229.

Mousa, S., Miller, C.H., Couri, D., 1981. Corticosteroid modulation and stress-induced analgesia in rats. Neuroendocrinology 33 , 317-319. 
Nonogaki, K., Iguchi, A., 1997. Stress, acute hyperglycemia, and hyperlipidemia. Role of the autonomic nervous system and cytokines. Trends Endocrinol. Metab. 8, 192-197.

Oddie, S.D., Bland, B.H., 1998. Hippocampal formation theta activity and movement selection. Neurosci. Biobehav. Rev. 22, 221-231.

Ohno, T., Kuroshima, A., 1986. Metyrapone-induced thermoregenesis in cold- and heat-acclimated rats. Jpn. J. Physiol. 36, 821825.

Parvez, H., Parvez, S., 1973. The effects of metopirone and adrenalectomy on the regulation of the enzymes monoamine oxidase and catechol-o-methyl transferase in different brain regions. J. Neurochem. 20, 1011-1020.

Paul, S.M., Purdy, R.H., 1992. Neuroactive steroids. FASEB J. 6, 2311-2322.

Peinnequin, A., Mouret, C., Birot, O., Alonso, A., Mathieu, J., Clarençon, D., Agay, D., Chancerelle, Y., Multon, E., 2004. Rat pro-inflammatory cytokine and cytokine related mRNA quantification by real-time polymerase chain reaction using SYBR green. BMC Immunol. 5.

Pryce, G., Giovannoni, G., Baker, D., 2003. Mifepristone or inhibition of $11 \beta$-hydroxylase activity potentiates the sedating effects of the cannabinoid receptor-1 agonist $\delta(9)$-tetrahydrocannabinol in mice. Neurosci. Lett. 341, 164-166.

Raven, P.W., Checkley, S.A., Taylor, N.F., 1995. Extra-adrenal effects of metyrapone include inhibition of the 11-oxoreductase activity of 11ß-hydroxysteroid dehydrogenase: a model for 11-HSO I deficiency. Clin. Endocrinol. (Oxf.) 43, 637-644.

Raven, P.W., O'Dwyer, A.-M., Taylor, N.F., Checkley, S.A., 1996. The relationship between the effects of metyrapone treatment on depressed mood and urinary steroid profiles. Psychoneuroendocrinology 21, 277-286.

Reddy, D.S., 2006. Physiological role of adrenal deoxycorticosteronederived neuroactive steroids in stress-sensitive conditions. Neuroscience 138, 911-920.

Ricart-Jané, D., Rodriguez-Sureda, V., Benavides, A., PeinadoOnsurbe, J., Lopez-Tejero, D.M., Llobera, M., 2002. Immobilization stress alters intermediate metabolism and circulating lipoproteins in the rat. Metabolism 51, 925-931.

Rivas, E., de Ceballos, M.L., Nieto, O., Fontenla, J.A., 1999. In vivo effects of new inhibitors of catechol-O-methyl transferase. Br. J. Pharmacol. 126, 1667-1673.

Roozendaal, B., Bohus, B., McGaugh, J.L., 1996. Dose-dependent suppression of adrenocortical activity with metyrapone: effects on emotion and memory. Psychoneuroendocrinology 21, 681693.

Rotllant, D., Armario, A., 2005. A single dose of metyrapone caused long-term dysregulation of the hypothalamic-pitituary-adrenal axis in the rat. Neuroscience 130, 427-434.

Rotllant, D., Ons, S., Carrasco, J., Armario, A., 2002. Evidence that metyrapone can act as a stressor: effect on pituitary-adrenal hormones, plasma glucose and brain c-fos induction. Eur. J. Neurosci. 16, 693-700.

Rupprecht, R., di Michele, F., Hermann, B., Ströhle, A., Lancel, M., Romeo, E., Holsboer, F., 1998. Neuroactive steroid concentrations following metyrapone administration in depressed patients and healthy volunteers. Biol. Psychiatry 44, 912-914.

Sandi, C., Venero, C., Guaza, C., 1996. Novelty related rapid locomotor effects of corticosterone in rats. Eur. J. Neurosci. 8, 794800.

Selye, H., 1950. Stress and the general adaptation syndrome. Br. Med. J. 1383-1392.

Senba, E., Ueyama, T., 1997. Stress-induced expression of immediate early genes in the brain and peripheral organs of the rat. Neurosci. Res. 29, 183-207.

Sgoifo, A., Pozzato, C., Meerlo, P., Costoli, T., Manghi, M., Stilli, D., Olivetti, G., Musso, E., 2002. Intermittent exposure to social defeat and open-field test in rats: acute and long term effects on ECG, body temperature and physical activity. Stress 5, 23-35.

Slawinska, U., Kasicki, S., 1998. The frequency of rat's hippocampal theta rhythm is related to the speed of locomotion. Brain Res. 796, 327-331.

Smith-Swintosky, V.L., Pettigrew, L.C., Sapolsky, R.M., Phares, C., Craddock, S.D., Brooke, S.M., Mattson, M.P., 1996. Metyrapone, an inhibitor of glucocorticoid production, reduces brain injury induced by focal and global ischemia and seizures. J. Cerebr. Blood Flow Metab. 16, 585-598.

Vandesompele, J., De Preter, K., Pattyn, F., Poppe, B., Van Roy, N., De Paepe, A., Speleman, F., 2002. Accurate normalization of realtime quantitative RT-PCR data by geometric averaging of multiple internal control genes. Genome Biol. 3 research 0034.00310034.0011.

Verleye, M., Akwa, Y., Liere, P., Ladurelle, N., Pianos, A., Eychenne, B., Schumacher, M., Gillardin, J.-M., 2005. The anxiolytic etifoxine activates the peripheral benzodiazepine receptor and increases the neurosteroid levels in rat brain. Pharmacol. Biochem. Behav. 82, 712-720.

Vinkers, C.H., de Jong, N., Kalkman, C.J., Westphal, K.G.C., van Oorschot, R., Olivier, B., Korte, S.M., Groenink, L., 2009. Stressinduced hyperthermia is reduced by rapid anxiolytic drugs independent of injection stress in rats. Pharamacol. Biochem. Behav. 93, 413-418.

Werner, R., 1988. Effect of metopirone-ditartrate on thermogenesis in the guinea-pig. Comp. Biochem. Physiol. C 90, 445-450.

Whishaw, I.Q., Vanderwolf, C.H., 1971. Hippocampal EEG and behavior: effects of variation in body temperature and relation of EEG to vibrissae movement, swimming and shivering. Physiol. Behav. 6, 391-397.

Williamson, D.G., O'Donnell, V.J., 1969. The interaction of Metopirone with adrenal mithochondrial cytochrome p-450. A mechanism for the inhibition of adrenal $11 \beta$-hydroxylation. Biochemistry (Mosc.) 8, 1306-1311.

Yau, J., Seckl, J., 2001. 11ß-Hydroxysteroid dehydrogenase type I in the brain; thickening the glucocorticoid soup. Mol. Psychiatry 6 , 611-614.

Zhao, H., Steinberg, G.K., Sapolsky, R.M., 2007. General versus specific actions of mild-moderate hypothermia in attenuating cerebral ischemic damage. J. Cerebr. Blood Flow Metab. 27, 1879-1894. 